\title{
IMPACT OF COMPETITIVE LEVEL AND AGE ON THE STRENGTH AND ASYMMETRY OF YOUNG SOCCER PLAYERS
}

\author{
IMPACTO DO NIVEL COMPETITIVO EDA FAIXAETÁRIA SOBRE FORÇA EASSIMETRIADE \\ FUTEBOLISTAS JOVENS
}

Original Article

ARTIGO ORIGINAL

Artículo Original

\author{
IMPACTO DEL NIVEL COMPETITIVO Y FRANJA ETARIA EN LA FUERZA Y ASIMETRÍA DE \\ LOS FUTBOLISTAS JÓVENES
}

\begin{abstract}
Jacielle Carolina Ferreira ${ }^{1}$ (Physical Education Professional) Silvia Ribeiro Santos Araujo ${ }^{2}$ (Physical Education Professional)

Eduardo Mendonça Pimenta ${ }^{3}$

(Physical Education Professional)

Hans-Joachim Karl Menzel ${ }^{2}$

(Physical Education Professional)

Fabíola Bertú Medeiros ${ }^{2}$

(Physical Education Professional)

André Gustavo Pereira de Andrade 2

(Physical Education Professional)

Juliana de Melo Ocarino ${ }^{4}$

(Physiotherapist)

Mauro Heleno Chagas²

(Physical Education Professional)
\end{abstract}

1. Universidade Federal de Mato Grosso, School of Physical Education, Department of Physical Education, Computer Science, Metabolism, Exercise and Health (NAFIMES), Cuiabá, MT, Brazil. 2. Universidade Federal de Minas Gerais, School of Physical Education, Physiotherapy and Occupational Therapy, Department of Sports, Biomechanics Laboratory, Belo Horizonte, MG, Brazil. 3. Universidade Federal de Minas Gerais, School of Physical Education, Physiotherapy and Occupational Therapy, Department of Sports, Exercise Physiology Laboratory, Belo Horizonte, MG, Brazil. 4. Universidade Federal de Minas Gerais, Department of Physiotherapy, Belo Horizonte, MG, Brazil.

\section{Correspondence:}

Av. Fernando Corrêa da Costa, no 2367, Campus Universitário, Bairro Boa Esperança, Cuiabá, MG, Brazil. 78060-900. jacielleferreira@gmail.com

\begin{abstract}
Introduction: Muscular strength is an essential capacity for soccer players; however, the profile of this capacity has not yet been clearly established in young players. Objective: To compare muscular strength performance in the countermovement jump (CMJ) task and the presence of lower limb asymmetry among soccer athletes of the under 15 (U15), under 17 (U17) and under 20 (U20) categories, and between two teams of different competitive levels. Methods: One hundred and fifty one young soccer players of three different categories (U15, U17 and U20) from two teams in the Brazilian first and second divisions performed six vertical jumps in a system of two force plates. Ground reaction force (GRF) was used to calculate jump height and to obtain the variables Peak force $\left(F_{\text {MAX }}\right)$, Impulse $(I)$ and Peak power $\left(P_{\text {MAX }}\right)$ with regard to body mass and the respective asymmetry values. Results: No differences were found in the performance and asymmetry variable between the categories (Jump height: $p=0.23 ; F_{\text {MAX }}: p=0.15 ; 1: p=0.11 ; P_{\text {MAx }}: p=0.32 ; F_{\text {MAx }}$ asymmetry: $p=0.21 ;$ I asymmetry: $p=0.58 ; P_{\text {MAX }}$ asymmetry: $p=0.58$ ). The first division club had higher muscle strength and asymmetry values than the second division club (Jump height: $p<0.01 ; 1: p<0.01 ; P_{\text {MAx }}: p<0.01 ; F_{\text {MAx }}$ asymmetry: $p<0.01 ;$ I asymmetry: $p<0.01 ; P_{\text {MAX }}$ asymmetry: $p<0.01$ ), except for $F_{\text {MAX }}(p=0.63)$. No variable had an interaction effect (club $x$ category). Conclusion: As categories progress, jump height, relative $I, P_{\text {MAX }}$ and $F_{\text {MAX }}$ values and their respective asymmetries are stable. The asymmetry and strength performance of the first division club were higher than that of the second division club, except for $F_{\text {MAX }}$ indicating that the competitive level may influence strength performance and the development of asymmetry. Level of Evidence Il; Diagnostic study - Investigating a diagnostic test.
\end{abstract}

Keywords: Soccer; Muscle strength; Athletic performance; Youth sports.

\section{RESUMO}

Introdução: A força muscularé uma capacidade fundamental para futebolistas; entretanto, o perfil dessa capacidade ainda não está bem estabelecido em jogadores jovens. Objetivo: Comparar o desempenho de força muscular na tarefa de salto com contramovimento e a presença de assimetria entre membros inferiores entre atletas de futebol das categorias Sub 15, Sub 17 e Sub 20 e entre dois clubes de niveis competitivos diferentes. Métodos: Cento e cinquenta e um jogadores de futebol jovens de dois clubes da primeira e segunda divisão e de três categorias diferentes (Sub 15, Sub 17 e Sub 20) realizaram seis saltos verticais em um sistema de duas plataformas de força. A partir da força de reação de solo, calculou-se a altura do salto e foram obtidas as variáveis Força máxima ( $F_{\text {MAxx }}$, Impulso (I) e Potência máxima $\left(P_{\text {MAx }}\right)$ com relação à massa corporal e aos respectivos valores de assimetria. Resultados: Nenhuma variável de desempenho e assimetria foi diferente entre as categorias (Altura do salto: $p=0,23 ; F_{\text {MAX: }}: p=0,15 ; 1: p=0,11 ; P_{\text {MAX: }}$ $p=0,32$; Assimetria de $F_{\text {MÁx }}: p=0,21$; Assimetria de $I: p=0,58$; Assimetria de $\left.P_{\text {MAx }}: p=0,58\right)$. O clube de primeira divisão apresentou maior desempenho de força e maior assimetria do que o clube de segunda divisão (Altura do salto: $p<$ 0,$01 ; 1: p<0,01 ; P_{\text {MAx: }} p<0,01$; Assimetria de $F_{\text {MAx: }}: p<0,01$; Assimetria de l: $p<0,01$; Assimetria de $P_{\text {MÁx }}: p<0,01$, exceto para $F_{\text {MAx: }}(p=0,63)$. Nenhuma variável teve efeito de interação (clube x categoria). Conclusão: À medida que as categorias progridem, a altura do salto e os valores de $I, P_{\text {MAX }}$ e $F_{\text {MAX }}$ relativos e as respectivas assimetrias são estáveis. A assimetria e o desempenho de força do clube da primeira divisão foram maiores do que a do clube da segunda divisão, exceto para $F_{\text {MAxx }}$ mostrando que o nível competitivo pode influenciar o desempenho de força e o desenvolvimento de assimetria. Nível de evidência ll; Estudo diagnóstico - Investigação de um exame para diagnóstico.

Descritores: Futebol; Força muscular; Desempenho atlético; Esportes juvenis.

\section{RESUMEN}

Introducción: La fuerza muscular es una capacidad fundamental para los futbolistas, sin embargo, aún no está bien establecido el perfil de es a capacidad en jugadores jóvenes. Objetivo: Comparar el desempeño de fuerza muscular en la tarea de salto con contramovimiento y la presencia de asimetría entre miembros inferiores de atletas de fútbol de las categorías Sub15, Sub17 y Sub20, y entre dos clubes de fútbol de diferente nivel competitivo. Método: 151 futbolistas de dos clubes de primera y segunda división y tres categorías diferentes (Sub15, Sub17y Sub20) realizaron seis saltos verticales en un sistema de plataformas de fuerza. A partir de la fuerza de reacción de suelo, se calculó altura 
del salto y variables Fuerza máxima (FMÀX), Impulso (I) y Potencia máxima (PMÁX) relativas a la masa corporal y los respectivos valores de asimetría. Resultados: Ninguna variable de rendimiento y asimetría fue diferente entre las categorías (Altura: $p=0,23 ; F M A X X: p=0,15 ; 1: p=0,11 ; P M A ́ X: p=0,32 ; F M A ̀ X: p=0,21 ;$ Asimetría de I: $p=0,58$; Asimetría de PMÁX: $p=0,58)$. El club de la primera división ha presentado mayor rendimiento de fuerza y mayor asimetría que el club de la segunda división (Altura del salto: $p<0,01 ; 1: p<0,01 ; P M A ́ X: p<0,01$; Asimetría de FMÀX: $p<0,01$, asimetría de l: $p<0,01$, asimetría de PMÁX: $p<0,01)$, excepto para FMÀX: $(p=0,63)$. Ninguna variable ha presentado efecto de interacción (club x categoría). Conclusión: A medida que las categorías progresan, la altura del salto y los valores de IMP, PMAX Y FMAX relativos y las respectivas asimetrías se mantienen estables. La asimetría y el desempeño de fuerza del club de la primera división fueron mayores que del club de segunda división, excepto para FMAX, mostrando que el nivel competitivo puede influir en el desempeño de fuerza y en el desarrollo de asimetría. Nivel de evidencia ll; Estudio diagnóstico - Investigación de un examen para diagnóstico.

Descriptores: Fútbol; Fuerza muscular; Rendimiento atlético; Deportes juveniles.

\section{INTRODUCTION}

The ability to produce force and the presence of asymmetry between lower limbs have been studied because of their influence on performance ${ }^{1,2}$ and the occurrence of musculoskeletal injuries, ${ }^{3,4}$ respectively. Sports with asymmetric demands (e.g., soccer) may predispose athletes to asymmetry in several musculoskeletal properties, including the capacity to produce force. ${ }^{5}$ In soccer, one of the limbs is preferentially used for kicking, tackling, jumping, and landing and may result in a difference in muscle strength between lower limbs. ${ }^{6-8}$

According to a theoretical model proposed by Fousekis et al., ${ }^{9}$ different factors can induce asymmetry in soccer players. These include organized training time at a professional level, suggesting that exposure to the specific demands of a modality for a longer time would result in greater asymmetry. Hence, athletes of different competitive levels and ages could present different profiles in relation to strength capacity, as well as in relation to the presence of asymmetric force between limbs. Nevertheless, when assessing the impact of age and competitive level on the production of strength and development of asymmetry, the results are controversial. ${ }^{710-13}$

Some studies have shown a linear increase in muscular strength with advancing age. ${ }^{12,14,15}$ Accordingly, adult players of higher competitive level show superior strength than lower level players or amateurs. ${ }^{16,17}$ However, in young players, Malina et al. ${ }^{18}$ found no difference in strength among athletes classified by skill level, as determined using specific soccer tests. Obtaining data on strength capacity and the presence of asymmetry between lower limbs may help in understanding the basic motor profile of soccer players.

Thus, the objective of this study was to compare muscular strength during jumping with countermovement and the presence of asymmetry between lower limbs among soccer athletes of categories Sub15 (child category), Sub17 (youth category), and Sub20 (junior category) and between 2 clubs of different competitive levels.

\section{METHODS}

The study included 151 athletes from 2 soccer clubs, i.e., 1 from the first division (D1) and 1 from the second division (D2), of the Brazilian Soccer Championship, and categorized participants as Sub15, Sub17, and Sub20 (Table 1).

The study was approved (no. 687.909) by the local Ethics Committee and followed the principles of the Declaration of Helsinki of 1995 and Resolution no. 466/12 of the National Health Council. Athletes over 18 years of age and those under the age of 18 and their guardians signed an informed consent form.
Table 1. Mean and standard deviation values for sample data.

\begin{tabular}{c|c|c|c|c|c}
\hline Club & Category & $\begin{array}{c}\text { Age } \\
(\text { years })\end{array}$ & $\begin{array}{c}\text { Mass } \\
(\mathbf{k g})\end{array}$ & $\begin{array}{c}\text { Stature } \\
(\mathbf{c m})\end{array}$ & $\begin{array}{c}\text { Body fat } \\
(\mathbf{\%})\end{array}$ \\
\hline D1 & Sub15 $(\mathrm{n}=17)$ & $14,9 \pm 0,2$ & $67,6 \pm 8,9$ & $177,0 \pm 9,1$ & $10,9 \pm 2,2$ \\
\hline & Sub17 $(\mathrm{n}=33)$ & $16,3 \pm 0,6$ & $69,5 \pm 9,5$ & $176,6 \pm 8,5$ & $9,7 \pm 1,6$ \\
\hline & Sub20 $(\mathrm{n}=25)$ & $17,4 \pm 0,9$ & $75,4 \pm 7,6$ & $180,5 \pm 8,0$ & $11,1 \pm 2,5$ \\
\hline D2 & Sub15 $(\mathrm{n}=23)$ & $13,7 \pm 0,7$ & $62,4 \pm 8,8$ & $165,1 \pm 8,3$ & $11,1 \pm 2,1$ \\
\hline & Sub17 $(\mathrm{n}=27)$ & $15,5 \pm 0,6$ & $71,5 \pm 7,7$ & $174,3 \pm 8,6$ & $12,4 \pm 2,2$ \\
\hline & Sub20 $(\mathrm{n}=26)$ & $18,3 \pm 0,9$ & $72,7 \pm 9,3$ & $177,8 \pm 8,9$ & $10,7 \pm 1,2$ \\
\hline
\end{tabular}

$\mathrm{D} 1$ = Club first division; $\mathrm{D} 2$ = Club second division .

\section{Data collection}

Data collection was performed in soccer clubs. The athletes performed a countermovement jump test (CMJ), as standardized in previous studies, ${ }^{19,20}$ using a 2-force platform system (PLA3-1D-7KN/JBAZb, Staniak, Poland). To perform the test, athletes were instructed to squat to a self-selected level and then jump as high as possible, keeping their hands at their waist. Before the tests, a standard familiarization procedure was performed. Six valid attempts were made with a 60-s interval between attempts.

The force platform system recorded ground reaction force (GRF) at a sampling rate of $500 \mathrm{~Hz}$. GRF values were treated separately using the same initial moment obtained through the analysis of the overall curve. Absolute Maximum Force $\left(F_{\text {MAX }}\right)$ values were obtained, and the highest GRF value was recorded; Impulse (IMP) measured temporal integration of GRF; Maximum Power $\left(P_{\text {MAX }}\right)$ measured the highest value of instantaneous mechanical power; and CMJ height was obtained by application of the "impulse-moment" theorem. ${ }^{21}$ For each variable, the mean of 3 CMJ values with the highest total impulse was used. $F_{\text {MAX }}$ IMP, and $\mathrm{P}_{\text {MAX }}$ were normalized for body mass.

Asymmetry between lower limbs was calculated for each CMJ variable as Asymmetry $F_{\text {MAX }}\left(A F_{\text {MAX }}\right)$, Asymmetry IMP (AIMP), and Asymmetry $P_{\text {MAX }}$ $\left(A P_{M A X}\right)$. The calculation was performed as the percentage difference in strength between the weaker limb and stronger limb.,22,23

The athletes showed good stability for $\mathrm{CM},{ }_{1}{ }^{24}$ independent of the analyzed variable $\left(\mathrm{F}_{\text {MAX: }}: \mathrm{CCl}_{3,1}=0.99, \mathrm{IMP}: \mathrm{CCl}_{3,1}=0.96, \mathrm{P}_{\text {MAx }}: \mathrm{CCl}_{3,1}=0.94, \mathrm{p}<0.01\right)$.

\section{Statistical analysis}

The results from descriptive analysis of $\mathrm{CMJ}$ variables were expressed as mean and standard deviation. Two-way $(2 \times 3)$ analysis of variance (ANOVA) was performed to test the main club effects (D1 and D2), category (Sub15, Sub17, and Sub20), and the interaction effect on performance variables for CMJ and asymmetry. The Holm-Sidak post hoc test was applied as 
needed. To interpret the effect size $\left(\eta^{2}\right)$, the values available in the study by Field ${ }^{25}$ were used; these classify $\eta^{2}=0.10$ as small, $\eta^{2}=0.30$ as medium, and $\eta^{2}=0.50$ as large. The acceptable statistical power $\left(\omega^{2}\right)$ was 0.8 (Field, 2009). A type I error probability of 0.05 was accepted.

\section{RESULTS}

Descriptive data for muscle strength during CMJ are presented in Table 2.

For the variable jump height $(\mathrm{H})$, ANOVA identified absence of an interaction effect (Club $\times$ Category, $F_{2,145}=0.19 ; p=0.82 ; \eta^{2}=0.04 ; \omega^{2}=0.05$ ). However, there was a main effect for $\mathrm{Club}\left(F_{1,145}=18.16 ; \mathrm{p}<0.01\right.$; $\eta^{2}=0.33 ; \omega^{2}=0.99$ ). The jump height was higher for D1 (club first division) than for D2 (club second division). There was no main effect for the category $\left(F_{2,145}=1.49 ; p=0.23 ; \eta^{2}=0.10 ; w^{2}=0.13\right)$.

There was no interaction effect (Club $\times$ Category, $F_{2,145}=0.83 ; p=0.44$; $\left.\eta^{2}=0.08 ; \omega^{2}=0.05\right)$, main club effect $\left(F_{1,145}=0.24 ; p=0.63 ; \eta^{2}=0.04\right.$; $\left.\omega^{2}=0.05\right)$, or category $\left(F(2,145)=1.94 ; p=0.15 ; \eta^{2}=0.11 ; \omega^{2}=0.20\right)$ for the variable $F_{\text {MAX. }}$.

There was no interaction effect (Club $\times$ Category, $F_{2,145}=0.39$; $\left.p=0.68 ; \eta^{2}=0.05 ; \omega^{2}=0.05\right)$ for the variable IMP. However, there was a main effect for Club $\left(F_{1,145}=19.48 ; p<0.01 ; \eta^{2}=0.34 ; \omega^{2}=0.99\right)$. The IMP produced during $C M J$ was higher for $D 1$ than for $D 2$. There was no main effect for category $\left(F\left(F_{2,145}\right)=2.27 ; p=0.11 ; \eta^{2}=0.12 ; \omega^{2}=0.26\right)$.

There was no interaction effect (Club $\times$ Category, $F_{2,145}=0.10$; $\left.p=0.90 ; \eta^{2}=0.03 ; w^{2}=0.05\right)$ for the $P_{\text {MAX }}$ variable. However, there was a main effect for Club $\left(F_{1,145}=8.54 ; p<0.01 ; \eta^{2}=0.24 ; \omega^{2}=0.79\right)$. The $P_{\text {MAX }}$ during CMJ was higher for D1 than for D2. There was no main effect for category $\left(F(2,145)=1.15 ; p=0.32 ; \eta^{2}=0.09 ; \omega^{2}=0.07\right)$.

The AFM data during the $\mathrm{CMJ}$ are presented in Table 3. There was no interaction effect (Club $\times$ Category, $F_{2,145}=0.63 ; p=0.53 ; \eta^{2}=0.07$; $\left.\omega^{2}=0.05\right)$ for the variable $A F_{\text {MAX }}$. However, there was a main effect for Club $\left(F_{1,145}=12.21 ; p<0.01 ; \eta^{2}=0.28 ; \omega^{2}=0.93\right) . A_{\text {MAX }}$ during CMJ was higher for D1 than for D2. There was no main effect for category $\left(F(2,145)=1.57 ; p=0.21 ; \eta^{2}=0.10 ; \omega^{2}=0.14\right)$.

There was no interaction effect (Club $\times$ Category, $F_{2,145}=0.46$; $\left.p=0.63 ; \eta^{2}=0.06 ; \omega^{2}=0.05\right)$ for the AIMP variable. However, there was a main effect for Club $\left(F_{1.145}=9.35 ; p<0.01 ; \eta^{2}=0.25 ; \omega^{2}=0.98\right)$. The AIMP during CMJ was higher for D1 than for D2.

There was no main effect for category $(F(2,145)=0.54 ; \mathrm{p}=0.58$; $\left.\eta^{2}=0.06 ; \omega^{2}=0.05\right)$.

There was no interaction effect (Club $\times$ Category, $F_{2,145}=0.55$; $\left.p=0.58 ; \eta^{2}=0.06 ; \omega^{2}=0.05\right)$ for the $\mathrm{AP}_{\text {Max }}$ variable. However, there was a main effect for $\mathrm{Club}\left(F_{1.145}=12.99 ; \mathrm{p}<0.01 ; \eta^{2}=0.29 ; \omega^{2}=0.95\right)$. The $\mathrm{AP}_{\text {MAX }}$ during the $\mathrm{CMJ}$ was higher for $\mathrm{D} 1$ than for $\mathrm{D} 2$. There was no main effect for category $\left(F(2,145)=0.55 ; p=0.58 ; \eta^{2}=0.06 ; \omega^{2}=0.05\right)$.

Table 2. Relative force values in countermovement jump (CMJ) (mean \pm standard deviation) for 2 clubs and 3 categories.

\begin{tabular}{|c|c|c|c|c|}
\hline Clubs & Variable & Sub15 & Sub17 & Sub20 \\
\hline \multirow{4}{*}{ D1 } & $\mathrm{H}(\mathrm{cm})^{*}$ & $40,64 \pm 11,91$ & $41,07 \pm 10,66$ & $43,19 \pm 10,14$ \\
\hline & $\mathrm{F}_{\operatorname{MAX}}(\mathrm{N} / \mathrm{kg})$ & $25,03 \pm 3,61$ & $25,01 \pm 4,09$ & $26,78 \pm 2,83$ \\
\hline & IMP $(\mathrm{Ns} / \mathrm{kg})^{*}$ & $2,80 \pm 0,40$ & $2,82 \pm 0,35$ & $2,89 \pm 0,33$ \\
\hline & $P_{\operatorname{MAX}}(W / k g) *$ & $29,32 \pm 4,75$ & $29,34 \pm 4,32$ & $30,79 \pm 3,87$ \\
\hline \multirow{4}{*}{ D2 } & $\mathrm{H}(\mathrm{cm})$ & $32,67 \pm 11,99$ & $35,47 \pm 5,39$ & $36,93 \pm 3,72$ \\
\hline & $\mathrm{F}_{\text {MAX }}(\mathrm{N} / \mathrm{kg})$ & $25,31 \pm 3,08$ & $25,16 \pm 2,66$ & $25,59 \pm 2,06$ \\
\hline & IMP (Ns/kg) & $2,50 \pm 0,41$ & $2,63 \pm 0,21$ & $2,69 \pm 0,14$ \\
\hline & $P_{\operatorname{MAX}}(W / k g)$ & $27,22 \pm 6,59$ & $27,56 \pm 3,64$ & $28,25 \pm 2,85$ \\
\hline
\end{tabular}

Table 3. Asymmetry values in the countermovement jump (CMJ) (mean \pm standard deviation) for 2 clubs and 3 categories.

\begin{tabular}{c|c|c|c|c}
\hline Clubs & Variable & Sub15 & Sub17 & Sub20 \\
\hline \multirow{4}{*}{ D1 $^{*}$} & $\mathrm{AF}_{\text {MAX }}(\%)$ & $8,03 \pm 4,73$ & $8,26 \pm 4,97$ & $8,63 \pm 3,81$ \\
\cline { 2 - 5 } & $\operatorname{AIMP}(\%)$ & $24,30 \pm 11,60$ & $25,56 \pm 11,43$ & $26,46 \pm 13,18$ \\
\cline { 2 - 5 } & $\mathrm{AP}_{\text {MAX }}(\%)$ & $27,04 \pm 12,38$ & $28,38 \pm 12,35$ & $29,18 \pm 14,51$ \\
\hline \multirow{4}{*}{ D2 } & $\mathrm{AF}_{\text {MAX }}(\%)$ & $4,99 \pm 4,00$ & $5,23 \pm 3,73$ & $7,26 \pm 4,21$ \\
\cline { 2 - 5 } & $\mathrm{AIMP}(\%)$ & $20,24 \pm 15,40$ & $16,92 \pm 9,02$ & $20,79 \pm 11,41$ \\
\cline { 2 - 5 } & $\mathrm{AP}_{\text {MAX }}(\%)$ & $21,75 \pm 15,92$ & $17,80 \pm 9,29$ & $22,09 \pm 11,85$ \\
\hline
\end{tabular}

Legend: D1 = Club first division; D2 = Club second division; Sub15 = Children category; Sub17 = Youth category; Sub20 = Junior category; "AF MAX $^{\prime \prime}=$ Asymmetry of maximum force; "AlMP" = Asymmetry of impulse; "AP MAX" $^{\prime \prime}=$ Asymmetry of maximum power; ${ }^{*}$ Main significant effect among clubs $(p<0.05)$.

\section{DISCUSSION}

The results of this study did not confirm the hypothesis that strength and asymmetry would increase with category progression. However, the data confirmed the hypothesis that athletes of higher competitive level would show greater strength and asymmetry.

The proposed hypothesis regarding muscle strength was not confirmed, despite being in agreement with previous studies showing an age effect on lower limb muscle strength in soccer players. ${ }^{12,14}$ A study by Buchheit et al. ${ }^{14}$ showed an increase in CMJ performance across categories (Sub13, Sub14, Sub15, Sub16, Sub17, and Sub18), but there was a plateau between Sub15 and Sub16 categories and between Sub17 and Sub18 categories. A study by Kellis et al..$^{12}$ used isokinetic dynamometry, and age was found to influence relative and absolute torque of knee flexion and extension in athletes aged 10-17 years. On the basis of these findings, it is possible to propose that there is a stabilizing trend in strength between Sub15 and Sub20 categories when measured using vertical jump height and performance variables related to body mass. However, this may not occur if force is evaluated in isolated muscle groups. In isokinetic dynamometry, it is possible that another normalization procedure, such as allometry, should be used for adequate comparison between groups. ${ }^{26}$

The differences in the pattern of muscle activation found between isokinetic dynamometry used by Kellis et al. ${ }^{12}$ and CMJ used in the present study may help to explain the controversial results. Isokinetic dynamometry has the advantage of evaluating isolated muscle groups and most often involves open kinetic chain actions; however, in CMJ, the recorded GRF results from the sum of moments of force and is a closed kinetic chain action. Moreover, in isokinetic dynamometry, muscular action is either concentric or eccentric under constant angular velocity, whereas in CMJ, concentric action is preceded by eccentric action (i.e., stretch-shortening cycle), with different angular velocities.

When comparing soccer players of different ages, a greater percentage in the 11-year age group than in the 9-year group had $>15 \%$ asymmetry, suggesting that asymmetry increases with age, ${ }^{11}$ thereby reinforcing the hypothesis proposed and the theoretical base model. ${ }^{9}$ However, in the present research, none of the asymmetry variables were different between categories. This finding is corroborated by Kellis et al. ${ }^{11}$ who also found no differences in asymmetry between players of different ages (10 to 17 years). However, Lehance et al. ${ }^{28}$ still suggested that asymmetry decreases with age, through observation of more athletes with asymmetry in the categories Sub17 and Sub21 than in the professional categories. When comparing the results of these studies, caution should be exercised in relation to possible effects of maturation level, which was only considered in a study by Buchheit et al. ${ }^{14}$

By using comparative data, it is expected that different categories will apply organized practice time using different modalities. However, this 
relationship cannot be guaranteed, as no individual systematic training time data were obtained for different groups. This is a limitation of this study, as the theoretical model could not be disproved. On the basis of the results of the present study, those reported by Lehance et al. ${ }^{28}$ and those reported by the authors who proposed the model, it is possible that longer practice time does not lead to greater asymmetry. Thus, players with longer professional training times showed less asymmetry in knee flexion ${ }^{9}$, which, according to the authors, is a neuromuscular preventive strategy against fatigue and injury adopted by more experienced players. This explanation can be considered viable as a more balanced use of lower limbs can be achieved by specific training. ${ }^{2}$ This fact does not reject the theoretical model, as higher loads with asymmetric demand would not cause greater asymmetry; however, the theoretical model would be rejected, as greater time in organized practice does not increase the development of unilateral characteristics, since athletes can adopt more balanced use between the limbs to perform motor tasks in soccer. Future studies that consider the grouping of athletes by training time and role in the game, and not by age group, can contribute to clarify the effect of asymmetry in young soccer players.

In a comparison between competitive levels, it was hypothesized greater strength and asymmetry of the first division club due to the fact that athletes at this competitive level would perform motor actions (e.g., acceleration, change of direction, jumping) involving greater forces and would possibly be exposed to a longer period of training practice and high-level competition.

In addition, previous studies have suggested that higher-level adult players have superior strength compared with lower-level or amateur players, ${ }^{16,17}$ corroborating the findings of the present study in young players. Malina et al. ${ }^{18}$ found no differences in muscle strength among young players (aged 13 to 15 years) of different skill levels. Nevertheless, it should be considered that grouping was performed by skill level among athletes of the same competitive level, who were likely to undergo similar training routines. The fact that $F_{\text {MAX }}$ presents a different behavior in relation to IMP and $P_{\text {MAX }}$ can be explained by the low influence of $F_{\text {MAX }}$ on short-term muscular action, as in the CMJ task. Menzel et al..$^{29}$ found a low-to-moderate correlation between $\mathrm{F}_{\text {MAX }}$ and the variables of IMP and $P_{\text {MAX }}$, whereas the correlation between IMP and $P_{\text {MAX }}$ was almost perfect, suggesting that both are influenced by similar factors.

Adult soccer players in the first and second division showed similar levels of asymmetry, as measured in the isokinetic test. ${ }^{13}$ In base category athletes, the comparison between clubs is still lacking. It is believed that this is one of the first studies to compare the profile of asymmetry between young athletes of different competitive levels. The differences identified among clubs may reinforce part of the theoretical model of Fousekis et al. ${ }^{9}$ when considering that a club in the first division can impose a longer weekly time of organized practice and greater participation in games for base categories in comparison with a club in the second division.

\section{CONCLUSIONS}

As categories progress, jump height and relative IMP, $\mathrm{P}_{\text {MAX, }}$ and $\mathrm{F}_{\text {MAX }}$ values and their respective asymmetries remain stable. In a comparison between clubs, asymmetry and strength of a first division club were greater than those of a second division club, except for $F_{\text {MAX }}$, showing that the competitive level may influence strength and the development of asymmetry. It is still possible to define reference values for strength and asymmetry using the CMJ task in young soccer athletes.

All authors declare no potential conflict of interest related to this article.

AUTHORS' CONTRIBUTIONS: Each author contributed individually and significantly to the development of this article. Jacielle Carolina Ferreira (0000-0002-9321-749X)*: Substantial contribution to work conception and data interpretation; writing the article; Silvia Ribeira Santos Araújo (0000-0002-4864-8821)*: Substantial contribution to work conception, data interpretation, and statistical analysis; Fabíola Bertu (0000-0002-2057-199X)*: Substantial contribution to data acquisition and data analysis; Hans Joachim Karl Menzel (0000-00017448-9636)*: Critical review of intellectual content and statistical analysis; Eduardo Mendonça Pimenta (0000-0001-8968-0089)*: Substantial contribution to data acquisition and critical review of intellectual content; André Gustavo Pereira de Andrade (0000-0003-3406-4558)*: Critical review of intellectual content and statistical analysis; Juliana de Melo Ocarino (00000001-9404-1695)*: Substantial contribution to work conception and data interpretation, and critical review of intellectual content; Mauro Heleno Chagas (0000-0002-1955-8990)*: Substantial contribution to work conception and data interpretation, and critical review of intellectual content. *ORCID (Open Researcher and Contributor ID).

\section{REFERENCES}

1. Hart NH, Spiteri T, Lockie RG, Nimphius S, Newton RU. Detecting deficits in change of direction performance using the preplanned multidirectional Australian football league agility test. J Strength Cond Res. 2014;28(12):3552-6.

2. Guilherme J, Garganta J, Graça A, Seabra A. Effects of technical training in functional asymmetry of lower limbs in young soccer players. Rev Bras Cineantropom Desempenho hum. 2015;17(2):125-35.

3. Croisier J, Ganteaume S, Binet J, Genty M, Ferret J. Strength imbalances and prevention of hamstring injury in professional soccer players a prospective study. Am J Sports Med. 2008;36(8):1469-75.

4. Fousekis K, Tsepis E, Poulmedis P, Athanasopoulos S, Vagenas G. Intrinsic risk factors of non-contact quadriceps and hamstring strains in soccer: a prospective study of 100 professional players. Br J Sports Med. 2011;45(9):709-14.

5. Oliveira ASC, Barbieri FA, Gonçalves M. Flexibility, torque and kick performance in soccer: Effect of dominance. Sci Sports. 2013;28(3):e67-70.

6. Blache $Y$, Monteil K. Contralateral strength imbalance between dominant and non-dominant lower limb in soccer players. Sci Sports. 2012;27(3):e1-e8.

7. Atkins S, Bentley I, Hurst HT, Hesketh C, Sinclair J. The presence of bilateral imbalance of the lower limbs in elite youth soccer players of different ages. J Strength Cond Res. 2016;30(4):1007-13.

8. Spagnuolo DL, Machado FA, Peccin MS. Evaluation of symmetry and weight-bearing in lower limbs of youth soccer players. Rev Bras Med Esporte. 2013;19(6):442-7.

9. Fousekis $K$, Tsepis E, Vagenas G. Lower limb strength in professional soccer players: profile, asymmetry, and training age. J Sports Sci Med. 2010;9(3):364-73.

10. Fousekis $K$, Tsepis $E$, Vagenas G. Multivariate isokinetic strength asymmetries of the knee and ankle in professional soccer players. J Sports Med Phys Fitness. 2010;50(4):465-74.

11. Sannicandro I, Quarto A, Piccinno A, Cofano G, Rosa RA. Lower limb functional asymmetries in young soccer players: do differences exist between different age groups? Br J Sports Med. 2014;48:657.

12. Kellis S, Gerodimos V, Kellis E, Manou V. Bilateral isokinetic concentric and eccentric strength profiles of the knee extensors and flexors in young soccer players. IES. 2001;9(1):31-9.

13. Maly T, Zahalka F, Mala L. Muscular strength and strength asymmetries in elite and sub-elite professional soccer players. Sport Science. 2014;7(1):27-34.

14. Buchheit M, Mendez-Villanueva A, Simpson BM, Bourdon PC. Match running performance and fitness in youth soccer. Int J Sports Med. 2010;31(11):818-25

15. Mirkov DM, Kukolj M, Ugarkovic D, Koprivica V, Jaric S. Development of anthropometric and physical performance profiles of young elite male soccer players: a longitudinal study. J Strength Cond Res. 2010;24(10):2677-82.

16. Cometti G, Maffiuletti NA, Pousson M, Chatard JC, Maffulli N. Isokinetic strength and anaerobic power of elite, subelite and amateur French soccer players. Int J Sports Med. 2001;22(1):45-51.

17. Gissis I, Papadopoulos C, Kalapotharakos VI, Sotiropoulos A, Komsis G, Manolopoulos E. Strength and speed characteristics of elite, subelite, and recreational young soccer players. Res Sports Med. 2006;14(3):205-14

18. Malina RM, Ribeiro B, Aroso J, Cumming SP. Characteristics of youth soccer players aged 13-15 years classified by skill level. Br J Sports Med. 2007;41(5):290-5.

19. Markovic S, Mirkov DM, Nedeljkovic A, Jaric S. Body size and countermovement depth confound relationship between muscle power output and jumping performance. Hum Mov Sci. 2014;33:203-10.

20. Claudino JG, Mezêncio B, Soncin R, Ferreira JC, Valadão PF, Takao PP, et al. Desenvolvimento de um método de familiarização individualizado para saltos verticais. Rev Bras Med Esporte. 2013;19(5):359-62

21. Linthorne NP. Analysis of standing vertical jumps using a force platform. Am J Phys. 2001;69(11):1 198-204.

22. Impellizzeri FM, Rampinini E, Maffiuletti N, Marcora SM. A vertical jump force test for assessing bilateral strength asymmetry in athletes. Med Sci Sports Exerc. 2007;39(11):2044-50.

23. Maulder P, Cronin J. Horizontal and vertical jump assessment: reliability, symmetry, discriminative and predictive ability. Phys Ther Sport. 2005;6(2):74-82

24. Walmsley RP, Amell TK. The application and interpretation of intraclass correlation in the assessment of reliability in isokinetic dynamometry. Isokinet Exerc Sci. 1996;6(2):117-24.

25. Field A. Descobrindo a estatística usando o SPSS. 2nd Ed. Porto Alegre: Artmed; 2009.

26. Cunha GS, Vaz MA, Oliveira AR. Normalização da força e torque muscular em crianças e adolescentes. Rev Bras Cineantropom Desempenho Hum. 2011;13(6):468-76.

27. Sannicandro I, Rosa RA, Pascalis SD, Piccinno A. The determination of functional asymmetries in the lower limbs of young soccer players using the countermovement jump. The lower limbs asymmetry of young soccer players. Sci Sports. 2012;27(6):375-7.

28. Lehance C, Binet J, Bury T, Croisier JL. Muscular strength, functional performances and injury risk in professional and junior elite soccer players. Scand J Med Sci Sports. 2009;19(2):243-51.

29. Menzel H, Chagas MH, Szmuchrowski LA, Araujo SR, Andrade AG, de Jesus-Moraleida FR. Analysis of Lower Limb Asymmetries by Isokinetic and Vertical Jump Tests in Soccer Players. J Strength Cond Res. 2013;27(5):1370-7. 